\title{
EMERGENT SHIFTS IN FACULTY DEVELOPMENT
}

\author{
A REFLECTIVE REVIEW
}

Shelda Debowski, University of Western Australia

Faculty development has largely focused on supporting the development of early-career academic skills in teaching and learning. Even recent discussions of how faculty developers might influence leaders and entire organizations have remained largely focused on teaching and learning issues. This chapter suggests the need to review and reform the role of faculty development to focus more holistically on the full nature of academic work and the evolving developmental needs of academics. It argues that the faculty developer's portfolio will need to expand to include support for academic research, career management, and leadership roles, as well as organizational development strategies to complement existing individual and instructional approaches.

From its origins in teaching and learning centers, faculty development has consolidated its focus on early-career academics and career management (Bach \& Sorcinelli, 2010). Recognizing the risks of focusing solely on promoting entry-level skills, Chism (2011) offers guidance on how faculty developers can influence the decisions and processes that underpin effective development of teaching and learning. It is heartening to see open discussions around the ways in which faculty development roles are being reenvisioned and expanded. But are these moves sufficient? Do we need to reengage more deeply with the function and purpose of faculty development and its potential for enriching the capabilities and capacity of our faculty?

\section{What Faculty Development Aims to Achieve}

An academic operates across a complex range of functions: teacher, researcher, consultant, communicator, leader, change agent, author. 
The expectations and standards of performance for academics have risen markedly and continue to do so. New academics have little lead time to learn the ropes and build credible profiles as both teachers and researchers. As they become established, they are also expected to consolidate their capabilities as leaders, collaborators, commentators, resource managers, and administrators. These multitudinous roles require expertise that goes significantly beyond the United States's and Australia's positioning of faculty development around support for new teachers.

The focus on teaching and learning can be traced back to the origins of faculty development in the 1970s when more students entered higher education and teaching and learning was identified as an area needing intensive support (Lee, Manathunga, \& Kandlbinder, 2008; Sorcinelli, Austin, Eddy, \& Beach, 2006). Pioneering work in faculty development was the foundation for, and continues to frame, much of our understanding of student learning (Tennant, McMullen, \& Kaczynski, 2010). The emphasis of faculty development on teaching and learning has rarely been challenged in the ensuing years. Certainly we have seen some gradual shifts as faculty development has expanded to encompass career management, mentorship, and, to a limited extent, leadership (Fullan \& Scott, 2008; Scott, Coates, \& Anderson, 2008). However, discussion of these support foci remains largely situated within a teaching and learning context, and the premise that faculty development should primarily support teaching and learning appears to have been largely unquestioned. Perhaps it is assumed that other academic capabilities relating to research competence and leadership skills do not need to be supported with ongoing learning, or perhaps other support units or professional organizations are believed to be addressing these needs.

\section{The Developmental Needs of Academics}

While the progress of academics as they move from novice to expert roles is still largely unmapped, recognition is growing that academics must acquire a vast array of skills and knowledge as they move into more senior responsibilities. An early-career academic is generally expected to demonstrate basic competencies in research and teaching while acculturating to the university. As individuals progress toward more senior roles, they require higher-level capabilities in managing people, resources, relationships, and outcomes. Four key growth areas that need to be demonstrated during an academic's career relate to teaching, research, career management, and leadership. 
New university teachers are given responsibility for designing and presenting instructional programs to students and must rapidly acquire entry-level capabilities in curriculum design, instructional strategies assessment, and student needs. Support for university teachers has primarily focused on offering newcomers a safe and supportive environment to develop basic capabilities (Hicks, Smigiel, Wilson, \& Luzeckyj, 2010). Additional support is needed as the teacher assumes additional responsibilities such as leadership of teaching teams or initiatives, mentorship of new teachers, reform of curricula, assessment of courses and programs of study, teaching more diverse student cohorts, and designing e-learning. Teachers are also expected to engage in regular evaluation of, and research relating to, the effectiveness of their existing strategies.

Most academics are also required to undertake significant research in their disciplines. However, the completion of a $\mathrm{Ph} . \mathrm{D}$. only marginally prepares an academic for independent research (Western et al., 2007). Like those who teach, those who research need to learn many new skills as they assume responsibility for their own research; other researchers; project management; collaboration; stakeholder relationship management; innovation; and strategic leadership of groups, centers, and research programs (Cohen \& Cohen, 2005; Debowski, 2007). Although grant management, research supervision of students, and research integrity are often addressed by units within the university and although national granting bodies are leading the movement to train graduate students to conduct and manage research, overall recognition of the broader capabilities required of research-active university staff is limited, and the needed capabilities are poorly supported in most university settings. A particular challenge is the determination of who should be responsible for supporting the development of research-active staff as they progress to leadership, management, and governance responsibilities.

Career management has become more necessary for academics as the competition for employment and tenure escalates. From an early focus on building a credible profile that fits institutional expectations, the academic must progressively build a strategic focus and a balanced portfolio that supports mobility and promotion by demonstrating a wide range of experiences and a depth of expertise.

Finally, academics are expected to assume more leadership responsibility as they progress in their careers. Initially focused on course or project management, these roles may gradually progress to responsibility for complex strategic outcomes, with expectations including management of issues of integrity, equity, and nurturing of effective sociocultural 
outcomes (Blackmore \& Sachs, 2007). Leaders of academic units play an integral role in building effective academic communities through their control of resource allocations, workload, values, and outcomes, and their capacity to motivate and stimulate a vigorous academic community (Del Favero, 2006; Gibbs, Knapper, \& Piccinin, 2008; Knight \& Trowler, 2001). They are responsible for encouraging high-quality teaching outcomes, productive and competitive research outputs, and an environment where new academics can flourish. However, effective leaders need considerable support to build self-awareness, an understanding of their role and obligations, and a repertoire of styles and approaches that will support their faculty and student needs.

Table 22.1 summarizes the activities academics might typically undertake at different stages in their career, illustrating the transitions that may occur and the synergies across areas of activity.

As academics progress through their careers, they move toward higherlevel roles in teaching, research, and leadership with responsibility for strategic deployment of people and resources. Research and teaching follow similar trajectories as academics move from building basic capabilities into the leadership and management of courses, projects, teams, and academic outcomes. At the same time, they may also assume more formal leadership roles in leading academic communities, such as discipline groups, schools, or faculties. A critical challenge in moving into a senior academic position is the coordination of teaching, research, and leadership roles to ensure that all are being well executed. Time, priorities, and career management are complex challenges, as they require a clear understanding of how academic success is measured within a particular context and more globally.

Table 22.1 highlights several key issues. First, the accommodation of the diversity of roles can be highly challenging, requiring ongoing learning to build existing capabilities. Second, the separation of support into discrete portfolios (teaching, research, career management, leadership) can be counterproductive, as the holistic nature of the development of an individual is then ignored and may lead to conflicting messages as to what is important. Third, the current focus on foundational and earlycareer support for academics ignores the major shifts in function and responsibility that occur as the academic moves to more influential roles. Fourth, the support offered through university development agencies is less effective if it is fragmented into different elements of the academic role. At present, for example, teaching and learning centers focus on the educational role, research units are solely focused on the research 
Table 22.I Functions of Effective Academic Work

Capabilities Teaching Research $\begin{gathered}\text { Career } \\ \text { Management Leadership }\end{gathered}$

Preentry (role orientation)

\begin{tabular}{|c|c|c|c|c|}
\hline $\begin{array}{l}\text { Role } \\
\text { familiarization }\end{array}$ & $\begin{array}{l}\text { Assist, } \\
\text { tutor, or } \\
\text { demonstrate } \\
\text { within } \\
\text { teaching } \\
\text { programs, } \\
\text { with } \\
\text { supervision. }\end{array}$ & $\begin{array}{l}\text { Conduct } \\
\text { supervised } \\
\text { research; apply } \\
\text { principles } \\
\text { of research } \\
\text { integrity. }\end{array}$ & $\begin{array}{l}\text { Develop a } \\
\text { curriculum } \\
\text { vitae; learn } \\
\text { about academic } \\
\text { work contexts. }\end{array}$ & $\begin{array}{l}\text { Undertake } \\
\text { local } \\
\text { leadership } \\
\text { roles; } \\
\text { participate } \\
\text { in service- } \\
\text { learning. }\end{array}$ \\
\hline $\begin{array}{l}\text { Foundational } \\
\text { skills } \\
\text { development }\end{array}$ & $\begin{array}{l}\text { Become } \\
\text { familiar with } \\
\text { teaching } \\
\text { and learning } \\
\text { theory and } \\
\text { methods. }\end{array}$ & $\begin{array}{l}\text { Learn research } \\
\text { methods. }\end{array}$ & Plan career. & $\begin{array}{l}\text { Learn } \\
\text { leadership } \\
\text { principles and } \\
\text { strategies. }\end{array}$ \\
\hline
\end{tabular}

Early career (core academic capabilities)

\begin{tabular}{|c|c|c|c|c|}
\hline Core knowledg & $\begin{array}{l}\text { Increase } \\
\text { specialist } \\
\text { skills and } \\
\text { knowledge. }\end{array}$ & $\begin{array}{l}\text { Increase } \\
\text { specialist } \\
\text { skills and } \\
\text { knowledge. }\end{array}$ & $\begin{array}{l}\text { Develop a } \\
\text { balanced } \\
\text { portfolio of } \\
\text { activities. }\end{array}$ & $\begin{array}{l}\text { Contribute to } \\
\text { institutional } \\
\text { events and } \\
\text { initiatives. }\end{array}$ \\
\hline $\begin{array}{l}\text { Professional } \\
\text { skills }\end{array}$ & $\begin{array}{l}\text { Design, plan, } \\
\text { and evaluate } \\
\text { teaching } \\
\text { programs. }\end{array}$ & $\begin{array}{l}\text { Design, plan, } \\
\text { complete, } \\
\text { and evaluate } \\
\text { research } \\
\text { projects. }\end{array}$ & $\begin{array}{l}\text { Develop an } \\
\text { academic } \\
\text { portfolio; } \\
\text { manage time } \\
\text { and priorities. }\end{array}$ & $\begin{array}{l}\text { Identify } \\
\text { priorities and } \\
\text { strategies. }\end{array}$ \\
\hline $\begin{array}{l}\text { Knowledge } \\
\text { exchange }\end{array}$ & $\begin{array}{l}\text { Employ } \\
\text { teaching } \\
\text { approaches } \\
\text { that meet } \\
\text { student needs; } \\
\text { contribute } \\
\text { to teaching } \\
\text { networks. }\end{array}$ & $\begin{array}{l}\text { Cosupervise } \\
\text { research } \\
\text { students; } \\
\text { contribute } \\
\text { to research } \\
\text { networks. }\end{array}$ & $\begin{array}{l}\text { Establish } \\
\text { mentoring } \\
\text { relationships; } \\
\text { contribute to } \\
\text { communities of } \\
\text { practice. }\end{array}$ & $\begin{array}{l}\text { Mentor } \\
\text { others. }\end{array}$ \\
\hline Collaboration & $\begin{array}{l}\text { Build teaching } \\
\text { collaborations; } \\
\text { team-teach. }\end{array}$ & $\begin{array}{l}\text { Build research } \\
\text { collaborations; } \\
\text { contribute to } \\
\text { research teams. }\end{array}$ & $\begin{array}{l}\text { Build local and } \\
\text { disciplinary } \\
\text { networks. }\end{array}$ & $\begin{array}{l}\text { Contribute } \\
\text { to university } \\
\text { reforms and } \\
\text { innovations. }\end{array}$ \\
\hline
\end{tabular}




\begin{tabular}{|c|c|c|c|c|}
\hline $\begin{array}{l}\text { Outcomes: } \\
\text { funding, } \\
\text { sponsorship, } \\
\text { and publication }\end{array}$ & $\begin{array}{l}\text { Seek external } \\
\text { funding; } \\
\text { publish } \\
\text { teaching } \\
\text { outcomes. }\end{array}$ & $\begin{array}{l}\text { Seek external } \\
\text { funding; } \\
\text { publish } \\
\text { research } \\
\text { outcomes. }\end{array}$ & $\begin{array}{l}\text { Seek feedback } \\
\text { from sponsors } \\
\text { and mentors. }\end{array}$ & $\begin{array}{l}\text { Seek } \\
\text { opportunities } \\
\text { to learn } \\
\text { more about } \\
\text { leadership. }\end{array}$ \\
\hline $\begin{array}{l}\text { Institutional } \\
\text { expectations }\end{array}$ & $\begin{array}{l}\text { Manage } \\
\text { equitable } \\
\text { assessment } \\
\text { processes; } \\
\text { reflect quality } \\
\text { teaching } \\
\text { principles. }\end{array}$ & $\begin{array}{l}\text { Apply research } \\
\text { integrity } \\
\text { principles; } \\
\text { protect } \\
\text { intellectual } \\
\text { property. }\end{array}$ & $\begin{array}{l}\text { Identify } \\
\text { university } \\
\text { promotion } \\
\text { criteria. }\end{array}$ & $\begin{array}{l}\text { Adhere to } \\
\text { university } \\
\text { protocols and } \\
\text { requirements. }\end{array}$ \\
\hline
\end{tabular}

Additional midcareer functions (academic management)

\begin{tabular}{|c|c|c|c|c|}
\hline Core role & $\begin{array}{l}\text { Coordinate } \\
\text { courses and } \\
\text { programs of } \\
\text { study. }\end{array}$ & $\begin{array}{l}\text { Manage } \\
\text { and execute } \\
\text { research } \\
\text { projects. }\end{array}$ & $\begin{array}{l}\text { Increase } \\
\text { national and } \\
\text { international } \\
\text { profile and } \\
\text { impact. }\end{array}$ & $\begin{array}{l}\text { Undertake } \\
\text { institutional } \\
\text { leadership } \\
\text { roles. }\end{array}$ \\
\hline $\begin{array}{l}\text { Management } \\
\text { skills }\end{array}$ & $\begin{array}{l}\text { Coordinate } \\
\text { teaching } \\
\text { teams. }\end{array}$ & $\begin{array}{l}\text { Coordinate } \\
\text { research teams; } \\
\text { supervise } \\
\text { research } \\
\text { students and } \\
\text { staff. }\end{array}$ & $\begin{array}{l}\text { Contribute to } \\
\text { national and } \\
\text { international } \\
\text { initiatives. }\end{array}$ & $\begin{array}{l}\text { Participate on } \\
\text { committees } \\
\text { and working } \\
\text { bodies. }\end{array}$ \\
\hline $\begin{array}{l}\text { Institutional } \\
\text { expectations }\end{array}$ & $\begin{array}{l}\text { Contribute } \\
\text { to curriculum } \\
\text { reform and } \\
\text { program } \\
\text { quality } \\
\text { assurance. }\end{array}$ & $\begin{array}{l}\text { Contribute to } \\
\text { consolidation } \\
\text { and growth of } \\
\text { the research } \\
\text { community. }\end{array}$ & & $\begin{array}{l}\text { Reflect } \\
\text { principles } \\
\text { of equity } \\
\text { and ethical } \\
\text { practice; } \\
\text { manage risk. }\end{array}$ \\
\hline Collaborations & $\begin{array}{l}\text { Develop } \\
\text { collaborations } \\
\text { to strengthen } \\
\text { teaching } \\
\text { scholarship. }\end{array}$ & $\begin{array}{l}\text { Strengthen } \\
\text { research } \\
\text { collaborations. }\end{array}$ & $\begin{array}{l}\text { Seek } \\
\text { opportunities } \\
\text { to expand } \\
\text { impact; } \\
\text { mentor junior } \\
\text { colleagues. }\end{array}$ & $\begin{array}{l}\text { Establish } \\
\text { collaborative } \\
\text { links with } \\
\text { other leaders } \\
\text { within and } \\
\text { beyond the } \\
\text { university. }\end{array}$ \\
\hline $\begin{array}{l}\text { Funding and } \\
\text { sponsorship }\end{array}$ & $\begin{array}{l}\text { Seek } \\
\text { sponsorship } \\
\text { for innovative } \\
\text { teaching } \\
\text { projects. }\end{array}$ & $\begin{array}{l}\text { Establish } \\
\text { funding } \\
\text { history and } \\
\text { relationships } \\
\text { with key } \\
\text { stakeholders. }\end{array}$ & & $\begin{array}{l}\text { Prepare } \\
\text { submissions; } \\
\text { manage } \\
\text { budgets and } \\
\text { staff. }\end{array}$ \\
\hline
\end{tabular}




\begin{tabular}{|c|c|c|c|c|}
\hline $\begin{array}{l}\text { Generate } \\
\text { outcomes }\end{array}$ & $\begin{array}{l}\text { Improve } \\
\text { teaching } \\
\text { performance } \\
\text { and } \\
\text { effectiveness. }\end{array}$ & $\begin{array}{l}\text { Increase } \\
\text { research impact } \\
\text { and profile. }\end{array}$ & $\begin{array}{l}\text { Monitor } \\
\text { personal } \\
\text { impact and } \\
\text { performance. }\end{array}$ & $\begin{array}{l}\text { Monitor } \\
\text { group } \\
\text { impact and } \\
\text { performance. }\end{array}$ \\
\hline
\end{tabular}

Additional functions for senior academic (academic leadership)

\begin{tabular}{|c|c|c|c|c|}
\hline Key role & $\begin{array}{l}\text { Oversee major } \\
\text { curriculum } \\
\text { reform and } \\
\text { quality } \\
\text { outcomes } \\
\text { from teaching } \\
\text { and learning } \\
\text { activities } \\
\text { by the unit; } \\
\text { contribute to } \\
\text { national and } \\
\text { international } \\
\text { disciplinary } \\
\text { initiatives. }\end{array}$ & $\begin{array}{l}\text { Direct research } \\
\text { programs, } \\
\text { centers, } \\
\text { institutes; guide } \\
\text { new research } \\
\text { directions and } \\
\text { initiatives. }\end{array}$ & $\begin{array}{l}\text { Maintain track } \\
\text { record and } \\
\text { profile; nurture } \\
\text { and sponsor } \\
\text { protégés; } \\
\text { develop } \\
\text { succession } \\
\text { plan. }\end{array}$ & $\begin{array}{l}\text { Lead academic } \\
\text { unit in } \\
\text { teaching and } \\
\text { research; } \\
\text { contribute to } \\
\text { the growth of } \\
\text { the university } \\
\text { and the } \\
\text { discipline. }\end{array}$ \\
\hline $\begin{array}{l}\text { Influencing } \\
\text { function }\end{array}$ & $\begin{array}{l}\text { Influence the } \\
\text { theory and } \\
\text { practice of } \\
\text { teaching and } \\
\text { learning. }\end{array}$ & $\begin{array}{l}\text { Influence the } \\
\text { theory and } \\
\text { practice of } \\
\text { the research } \\
\text { domain. }\end{array}$ & $\begin{array}{l}\text { Ensure a } \\
\text { positive work } \\
\text { environment } \\
\text { for less senior } \\
\text { staff. }\end{array}$ & $\begin{array}{l}\text { Comment on } \\
\text { national and } \\
\text { international } \\
\text { issues; } \\
\text { advocate in } \\
\text { the media and } \\
\text { other forums. }\end{array}$ \\
\hline
\end{tabular}

process, and leadership and career management are largely unexplored in many universities. The key issue is evident: there are major gaps in support for faculty and their development.

\section{A Case Study: The Future Research Leaders Program}

In 2004 eight Australian organizational developers from the top researchintensive universities who were concerned about the evident gap in research development support interviewed thirty researchers across six universities. The human resource directors and deputy vice chancellors of research who received the resulting report recognized the need for researcher support, and their actions ultimately resulted in a milliondollar grant from the Australian government. With this money, nine 
online modules to assist researchers in commencing and then managing research projects were developed and rolled out to over one thousand researchers. The program continues to be sponsored by those eight universities and is now in place in other universities across two nations (www.go8.edu.au/university-staff/programs-a-fellowships/).

One of the major challenges and surprises of the project was the ownership of the development work. Amazingly, in all eight universities, faculty developers were not interested in participating in the project, despite, in some cases, strong encouragement from their deputy vice chancellors. Therefore, ownership resides with either human resource or research offices. The case highlights a risk for faculty developers of being marginalized through their disinterest in allied but different aspects of faculty support. The strong association of faculty development with teaching and learning has isolated faculty developers from the concept of also supporting other elements of academic activity. However, as the emerging discussions around leadership and organizational development illustrate (Schroeder, 2011), faculty developers can adapt and move into new roles if they see the need and relevance. Given their concern about being marginalized by university decision makers (Debowski, Stefani, Cohen, \& $\mathrm{Ho}$, in press), it could be time to take a fresh look at how faculty developers are positioned and future directions they might consider.

\section{A New Framework for Faculty Development}

Faculty development is a challenging field in that the role and focus can be highly variable, depending on a number of factors. Figure 22.1 offers an overview of the external drivers and internal approaches that influence the way faculty development in a particular university might operate. The model suggests four views of faculty development that influence the type of role and the methodologies adopted by developers.

First, the university expectations and context can influence how faculty development is perceived. Senior members of the university administration may have strong beliefs about priorities, leading to emphasis on particular functions. Where administrative portfolios are highly compartmentalized, so too may be the support for academics. Thus, the faculty developer role can be influenced by stakeholder expectations, institutional philosophy, and political structures. Second, the faculty development orientation that predominates is a strong influence. In Australia, for example, the majority of faculty developers see themselves as solely focused on supporting learning and teaching. There are some early 
signs of an emerging recognition of the holistic needs of academics and the need to recast the faculty developer role, but this could take some time to grow and gain credence. Third, the individual's role definition strongly guides what activities and priorities are supported. For example, a faculty developer who sees the role as primarily operating through the education and guidance of new academics will prioritize those activities, while another may see the need to work more intensively with academic leaders. Finally, the figure highlights the influence of research and scholarship in guiding how faculty developers view their work and their roles. A risk in this regard is that the research merely serves to reinforce existing assumptions and traditional approaches.

Figure 22.1 highlights the highly politicized context in which faculty development operates. There is potential for conflict, for example, when the university has expectations as to roles and outcomes that are differently configured from those held by the discipline or the developers. In recent years, there has been evidence of some university dissatisfaction with the way developers enact their roles, resulting in restructures,

Figure 22. I Professional Role of Future Faculty Developers

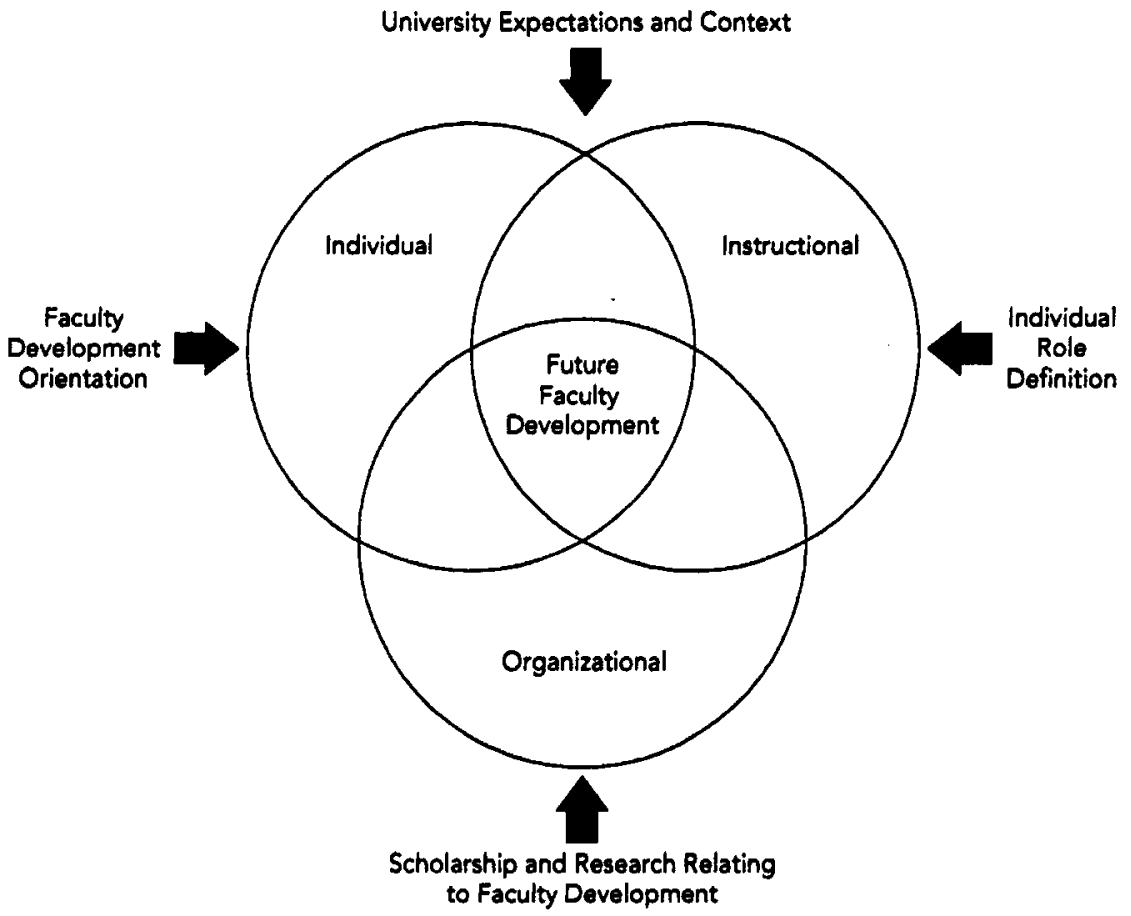


redundancies, and alternative recruitment strategies (Gosling, 2009). It could be argued that the need is increasing to build a stronger base of research, scholarship, and dialogue around the different ways in which faculty development roles may operate. In order to move from existing notions of faculty development to a more sophisticated understanding, Schroeder (2011) suggests that faculty developers need to be conversant with three levels of development: individual, instructional, and organizational.

\section{Individual Development}

Developing the early-career academic's teaching and learning capabilities has been a hallmark of faculty development for many years. Particular academics have benefited greatly from the dedication and expert support of developers as they review student feedback, develop academic portfolios, attend workshops, or address particular pedagogical challenges under the guidance of the developer. This coaching approach is timeconsuming, resource intensive, and largely hidden from university leaders. It may also result in little demonstrable systemic change.

It is important to note that the successful transfer of individual learning is strongly influenced by the context in which the learner works. A negative, judgmental community, for example, will limit an individual's willingness to take risks or try new approaches. And a positive, constructive community can encourage and promote innovation and good practice as desirable outcomes. The challenge is to balance the focus on individual learning with a commensurate concern for shifting the culture and practices of the broader institutional setting. The emerging squeeze on resources challenges us to review how we operate. Is there enough impact from working with single individuals? Can we build different approaches that encourage stronger ownership by faculty members? For example, a faculty development program within faculties (Debowski, 2007) increases the engagement of the entire community and can challenge many existing assumptions around supporting new or early-career faculty.

There is considerable potential in shifting the responsibility for individual development to peers and leaders within each academic area. That is, the faculty developer role shifts from capability building to capacity building. Coaching by faculty developers may shift in emphasis from assisting junior faculty toward developing leadership and management capabilities of senior faculty and administrators who can influence entire academic communities. 


\section{Instructional Development}

For many years, faculty development has emphasized programs relating to foundational skills in teaching and learning. Academic participants attend either out of personal interest or because they are required by their institutions. Obligatory attendance increases the demands on faculty developers who must ensure that sufficient access to the required programs is available to their target group. To meet this demand, there has been an increased emphasis on developing additional modes of instruction, including online delivery and graduate certification. The expansion of entry-level support to encompass career management and research strategies increases the demands on this instructional role and may require the development of additional early-career programs. The instructional development role is likely to increase in intensity and demand as the scope of faculty development work is further refined. A critical challenge for faculty developers is to remain visible and influential across the wider university community despite supporting larger numbers of entry-level academics. The shifting of support from a centralized model (where individuals attend a centralized course) to a customized model (where the developer goes to the learning community) offers many benefits for relationship building and influencing (Debowski, 2007). However, it increases the load on the developer even further. Thus, while the traditional instructional role remains critical, the scope and design of the programs could benefit from further critique and review.

\section{Organizational Development}

Faculty developers have the opportunity to influence whole faculty communities when they move into organizational development work (Debowski \& Blake, 2007; Latta, 2009). Working in partnership with their academic colleagues, developers can assist in identifying critical issues and offer guidance to community leaders as consultants, coaches, mentors, and facilitators. These partnerships might focus on amending existing practices, building common messages, or encouraging stronger consistency of values, beliefs, and practices. Developers can encourage academic leaders and their communities to take ownership of issues and move toward a deeper appreciation of their influence, roles, and responsibilities in achieving robust and effective academic communities. This work can be complex, long term, and highly influential, as it often deals with complicated and interrelated issues. It may require working with leadership teams as well as individuals. In undertaking this work, faculty 
developers need to be conversant with university policies and context. Developers working at the organizational level benefit from an awareness of the intertwining spheres of teaching, research, leadership, and career management.

A second influential role that can be undertaken by faculty developers is to broker networks and communities of practice (Debowski \& Blake, 2007). For example, targeted programs to support academic leaders are best designed as learning communities for particular cohorts, such as heads of schools or departments or faculty leaders in teaching and research spheres (Elkins \& Keller, 2003; Mumford, Hunter, Eubanks, Bedell, \& Murphy, 2007; Van Velsor, McCauley, \& Ruderman, 2010). Such senior programs are generally less focused on skill development, instead emphasizing capacity building, reflective practice, action learning, and self-awareness. They recognize the complex setting in which academics leaders operate (Goffee $\&$ Jones, 2007), and they may require a range of strategies, including diagnostic tools, intensive feedback, and longterm implementation plans that continue beyond the end of the program.

Organizational development work is a powerful tool for building strong collaborations with deans, heads of school, and whole communities. It offers enormous potential for influencing group behaviors and having an impact on the entire university as those leaders assume more informed roles in guiding institutional practice.

\section{Emergent Challenges for Faculty Development}

The determination of how best to operate depends on a number of factors, including institutional influences and the efficacy of developers themselves. University structures, policies, political initiatives, faculty developer capabilities, and agreed-on priorities for faculty development all determine the final mix of services. Developers face challenges in working outside traditional boundaries and in refocusing their work to create a more strategic and responsive service. While the opening of discussions about potential role expansion or enrichment may seem challenging or even risky, there are also major risks attached to accepting the status quo and failing to question whether more can be achieved from an effective development service.

The extension into three levels of faculty development (and possibly a broadened scope to include research and leadership) has a number of likely implications for how we define the work we do and the priorities we emphasize: 
- As the scope of faculty development expands to include research, career management, leadership, and organizational development, the ways in which we work with other service units will need to change. There is a large, invisible divide between faculty developers and organizational developers in many universities. However, the movement into organizational and leadership development support will need to draw on the professional expertise of allied professionals. Faculty developers can benefit from a larger theory base about how organizations operate and why people respond as they do to change. Diagnostic tools also enrich the evidence base that can be offered to participants. Research support units can assist in enriching learning around research strategy and outcomes. Mapping and discussion of the scope of support provided by various support units will help to identify opportunities for collaboration as well as avoid duplication.

- The promotion of organizational learning around academic work leads to informed and strong leadership across the university community. It encourages strong ownership of issues and solutions and builds learning partnerships with community leaders. This shift in focus also reduces the ascription of the developer as "the expert." Instead, developers are likely to move toward partnership models, where the desired outcomes and the pace of learning are negotiated with the learners, accommodating the particular contextual and environmental conditions that exist.

- The expansion of faculty development to include new areas of support requires better liaison with leaders across the university. Provosts and deans will need to be kept informed of new initiatives and given the opportunity to discuss strategic priorities and emergent needs. The support of these leaders can greatly improve the political positioning of the faculty development unit.

- Evaluation strategies are needed to show impact and influence. Existing measures of effectiveness will be less useful as we move toward stronger community engagement agendas. Consideration of this area is emerging (Debowski, 2011; Stefani, 2011), but more needs to be done.

- The broadening scope of faculty development requires careful prioritization of activities based on where the greatest impact can be achieved. While traditional areas of instructional and individual support are popular and well developed, they have far less impact on the larger community than organizational work does. Thus, a redesign of the service mix and its approaches may be needed.

- Many of the principles that operate in faculty development have been acquired from our understanding of how undergraduate students 
learn. But our clientele are experienced academics who bring considerable knowledge and expertise to their learning. Our current model is risky: new developers are commonly drawn from faculty and then simply relocated into developer roles where they learn the ropes from others or by trial and error. As we move into a broader conception of faculty development work, we will need to build rigorous accountability around how we perform our roles and the methodologies that we employ.

- The new areas discussed in this chapter require ongoing education of faculty developers. Expertise in adult learning, organizational development, leadership enhancement strategies, and research management would assist faculty developers in their roles. At present it appears that faculty developers learn about their role through self-education. More scholarship and support from professional societies would greatly assist in building a professional knowledge base.

From these brief reflections, it is apparent that faculty development has reached a crossroad. One path encourages the continuation of promoting and advancing teaching and learning as the sole professional emphasis. The other commences the process of integrating additional elements of faculty support into the professional repertoire. While the second path poses many complex challenges, it also offers considerable scope to increase the influence and recognition of the importance of faculty development work.

Ultimately the faculty development profession would benefit from a framework that articulates the professional knowledge and skills that faculty developers require to do their work. The long-established model of mirroring the practices that were applied as a faculty member is no longer acceptable as a basis for working with academics. Instead the development of organizational, instructional, and individual development skills is necessary for any faculty developer to operate with credibility. Professional societies can play a major role in guiding debate about these alternative futures and offering ongoing professional development for faculty developers. This is the next step in the process of reenvisioning the nature and function of faculty development.

\section{Conclusion}

The field of faculty development has made great strides since its beginnings in the 1970s, particularly in positioning our members as experts in learning and teaching. However, the existing model is fast approaching a point where it needs to be reviewed and challenged. We cannot continue 
to ignore the complex challenges that our constituents face in working as multidimensional research-intensive academics. We need additional expertise and reach to facilitate leadership and organizational learning. We need to identify the areas of influence that will be of the most benefit to our institutions and our own effectiveness.

It is time to reframe our concept of faculty development. We need to move from a traditional model to one that clearly works toward the betterment of the faculty experience and, by implication, the outcomes of the institution. It is time to review and articulate the purpose and goals of faculty development: to encourage stronger and more capable academics who can face complex challenges with confidence and courage across all areas of their work. We need to be the learning partners of choice in this ongoing process.

\section{REFERENCES}

Bach, D. J., \& Sorcinelli, M. D. (2010). The case for excellence in diversity: Lessons from an assessment of an early career faculty program. In L. B. Nilson \& J. E. Miller (Eds.), To improve the academy: Vol, 28. Resources for faculty, instructional, and organizational development (pp. 310-326). San Francisco, CA: Jossey-Bass.

Blackmore, J., \& Sachs, J. (2007). Performing and reforming leaders: Gender, educational restructuring, and organizational change. Albany: State University of New York Press.

Chism, N.V.N. (2011). Getting to the table: Planning and developing institutional initiatives. In C. M. Schroeder (Ed.), Coming in from the margins: Faculty development's emerging organizational development role in institutional change (pp. 47-59). Sterling, VA: Stylus.

Cohen, C. M., \& Cohen, S. L. (2005). Lab dynamics: Management skills for scientists. New York, NY: Cold Spring Harbor Laboratory Press.

Debowski, S. (2007). Finding the right track: Enabling early career academic management of career, teaching and research. Research and Development in Higher Education, 30, 138-149.

Debowski, S. (2011). Locating academic development: The first step in evaluation. In L. Stefani (Ed.), Evaluating the effectiveness of academic development (pp. 17-30). New York, NY: Routledge.

Debowski, S., \& Blake, V. (2007). Collective capacity building of academic leaders: A university model of leadership and learning in context. International Journal of Learning and Change, 2(3), 307-324.

Debowski, S., Stefani, L., Cohen, M., \& Ho, A. (in press). Sustaining and championing teaching and learning: In good times and bad. In J. Groccia, $M$. 
Alsudairi, \& B. Buskist (Eds.), Handbook of college and university teaching: Global perspectives. Thousand Oaks, CA: Sage.

Del Favero, M. (2006). Disciplinary variation in preparation for the academic dean role. Higher Education Research and Development, 25(3), 277-292. doi:10.1080/07294360600793069

Elkins, T., \& Keller, R. T. (2003). Leadership in research and development organizations: A literature review and conceptual framework. Leadership Quarterly, 14(4/5), 587-606. doi:10.1016/S1048-9843(03)00053-5

Fullan, M., \& Scott, G. (2009). Turnaround leadership for higher education. San Francisco, CA: Jossey-Bass.

Gibbs, G., Knapper, C., \& Piccinin, S. (2008). Disciplinary and contextually appropriate approaches to leadership of teaching in research-intensive academic departments in higher education. Higher Education Quarterly, 62(4), 416-436. doi:10.1111/j.1468-2273.2008.00402.x

Goffee, R., \& Jones, G. (2007). Leading clever people. Harvard Business Review, 85(3), 72-79.

Gosling, D. (2009). Educational development in the UK: A complex and contradictory reality. International Journal of Academic Development, 14(1), 5-18. doi:10.1080/13601440802659122

Hicks, M., Smigiel, H., Wilson, G., \& Luzeckyj, A. (2010). Preparing academics to teach in bigher education. Retrieved from www.altc.edu.au/ resource-preparing-academics-teach-higher-education-unisa-2010

Knight, P., \& Trowler, P. (2001). Departmental leadership in higher education. Buckingham, England: Society for Research into Higher Education \& Open University Press.

Latta, G. (2009). Maturation of organizational development in higher education: Using cultural analysis to facilitate change. In L. B. Nilson \& J. E. Miller (Eds.), To improve the academy: Vol. 27. Resources for faculty, instructional, and organizational development (pp. 32-71). San Francisco, CA: Jossey-Bass.

Lee, A., Manathunga, C., \& Kandlbinder, P. (2008). Making a place: An oral history of academic development in Australia. Canberra, Australia: Higher Education Research \& Development Society of Australasia.

Mumford, M. D., Hunter, S. T., Eubanks, D. L., Bedell, K. E., \& Murphy, S. T. (2007). Developing leaders for creative efforts: A domain-based approach to leadership development. Human Resource Management Review, 17(4), 402-417. doi:10.1016/j.hrmr.2007.08.002

Schroeder, C. M. (2011). Faculty developers as institutional developers. In C. M. Schroeder (Ed.), Coming in from the margins: Faculty development's emerging organizational development role in institutional change (pp. 17-46). Sterling, VA: Stylus. 
Scott, G., Coates, H., \& Anderson, M. (2008). Learning leaders in times of change: Academic leadership capabilities for Australian higher education. Sydney: University of Western Sydney/Australian Council for Educational Research.

Sorcinelli, M. D., Austin, A. E., Eddy, P. L., \& Beach, A. L. (2006). Creating the future of faculty development: Learning from the past, understanding the present. San Francisco, CA: Jossey-Bass.

Stefani, L. (Ed.). (2011). Evaluating the effectiveness of academic development. New York, NY: Routledge.

Tennant, M., McMullen, C., \& Kaczynski, D. (2010). Teaching, learning and research in higher education. New York, NY: Routledge.

Van Velsor, E., McCauley, C. D., \& Ruderman, M. N. (2010). Handbook of leadership development (3rd ed.). San Francisco, CA: Jossey-Bass.

Western, M., Boreham, P., Kubler, M., Laffan, W., Western, J., Lawson, A., \& Clague, D. (2007). PhD graduates 5 to 7 years out: Employment outcomes, job attributes and the quality of research training: Final report (Revised). Queensland, Australia: University of Queensland Social Research Centre. Retrieved from http://espace.library.uq.edu.au/view/ UQ:177864 